\title{
LA-UR- $09-00247$
}

Approved for public release;

distribution is unlimited.

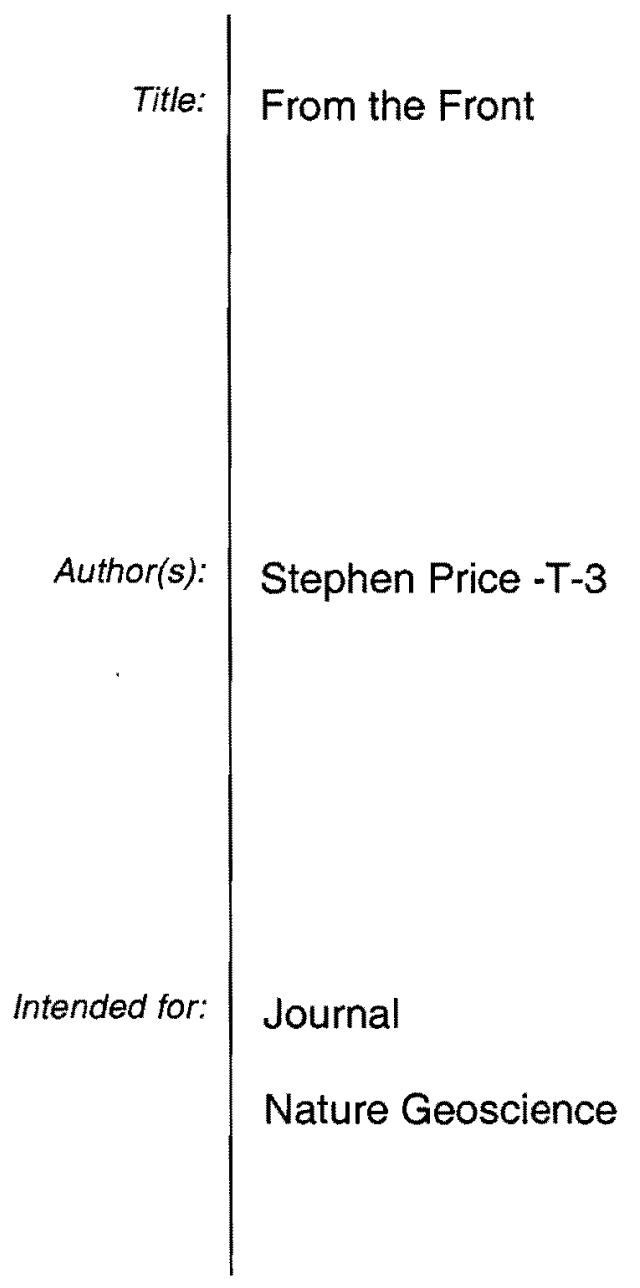

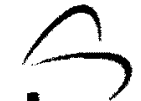 \\ - Los Alamos NATIONAL LABORATORY \\ EST.1943}

Los Alamos National Laboratory, an affirmative action/equal opportunity employer, is operated by the Los Alamos National Security, LLC for the National Nuclear Security Administration of the U.S. Department of Energy under contract DE-AC52-06NA25396. By acceptance of this article, the publisher recognizes that the U.S. Government retains a nonexelusive, royalty-free license to publish or reproduce the published form of this contribution, or to allow others to do so, for U.S. Government purposes. Los Alamos National Laboratory requests that the publisher identify this article as work performed under the auspices of the U.S. Department of Energy. Los Alamos National Laboratory strongly supports academic freedom and a researcher's right to publish; as an institution, however, the Laboratory does not endorse the viewpoint of a publication or guarantee its technical correctness. 
Strapline: Glaciology

Title: From the front

Stephen Price is with the COSIM project

Fluid Dynamics and Solid Mechanics Group

Los Alamos National Laboratory

Los Alamos, NM 87545

Standfirst: The causes of recent dynamic thinning of Greenland's outlet glaciers have been debated. Realistic simulations suggest that changes at the marine fronts of these glaciers are to blame, implying that dynamic thinning will cease once the glaciers retreat to higher ground.

For the last decade, many outlet glaciers in Greenland that terminate in the ocean have accelerated, thinned, and retreated. To explain these dynamic changes, two hypotheses have been discussed. Atmospheric warming has increased surface melting and may also have increased the amount of meltwater reaching the glacier bed, increasing lubrication at the base and hence the rate of glacier sliding ${ }^{1}$. Alternatively, a change in the delicate balance of forces where the glacier fronts meet the ocean could trigger the changes ${ }^{2,3,4}$. On page $\mathbf{x x x}$ of this issue, Faezeh Nick and colleagues ${ }^{5}$ present ice-sheet modeling experiments that mimic the observations on Helheim glacier, East Greenland, and suggest 
that the dynamic behaviour of outlet glaciers follows from perturbations at their marine fronts.

Greenland's ice sheet loses mass partly through surface melting and partly through fast flowing outlet glaciers that connect the vast plateau of inland ice with the ocean. As the outlet glaciers flow into the sea, icebergs calve from their fronts. As highlighted in the fourth assessment report of the Intergovernmental Panel on Climate Change ${ }^{6}$ (IPCC), earlier ice sheet models have failed to reproduce the dynamic variability exhibited by ice sheets over time. It has therefore not been possible to distinguish with confidence between basal lubrication from surface meltwater and changes at the glaciers' marine fronts as causes for the observed changes on Greenland's outlet glaciers.

But this distinction bears directly on future sea-level rise, the raison d'etre of much of modern-day glaciology: If the recent dynamic mass loss from Greenland's outlet glaciers is linked to changing atmospheric temperatures, it may continue for as long as temperatures continue to increase. On the other hand, if the source of the dynamic mass loss is a perturbation at the ice-ocean boundary, these glaciers will lose contact with that perturbation after a finite amount of thinning and retreat. Therefore, the first hypothesis implies continued retreat of outlet glaciers into the foreseeable future, while the second does not - provided the bedrock topography prohibits a connection between the retreating glacier and the ocean. 
Nick and coauthors ${ }^{5}$ test the physical mechanisms implied in each hypothesis in an innovative ice-flow model, and use that model to try to match a time series of observations from Helheim glacier, one of Greenland's three largest outlet glaciers. They find that a reduction in resistance at the glacier terminus - which might result, for example, from the loss of a floating ice tongue or a change in calving rate - triggers behaviour in the model that is in broad agreement with observations from $2001-2006^{7}$. Importantly, the model captures the observed pattern of a relatively minor initial acceleration, followed by more rapid acceleration and thinning as the glacier terminus retreats into deeper water across a bedrock low, followed by deceleration and stabilization as the glacier retreats into shallower water. In contrast, for experiments where basal lubrication was altered to simulate increased sliding from meltwater input, the modeled velocity and geometry show little similarity to the observations.

Along with many observations ${ }^{2-4,7-10}$, Nick and colleagues' simulations strongly support the contention that the recent retreat of Greenland's outlet glaciers is the result of changes at their marine fronts. Further, the simulations confirm the earlier hypotheses ${ }^{7}$ that bedrock topography largely controlled Helheim glacier's rapid acceleration and retreat in 2004 and 2005, and its deceleration and stabilization in 2006. Finally, the current work implies that, if requirements of observational data (high-resolution bed topography) and computational resources (fine computational grid resolution) can be met, improved predictive capability for ice-sheet models is attainable. With respect to the concerns raised by the IPCC, this study signals progress. 
With respect to ice sheet stability and sea-level rise, two important conclusions can be drawn from the simulations. First, peak discharge rates associated with the acceleration of Greenland's outlet glaciers could be short-lived. Because these glaciers adjust quickly, "snapshots" of Greenland's mass balance" that include these transient peaks are not necessarily indicative of Greenland's long-term contribution to sea level. The authors suggest that the competition between accumulation and melting, and not the dynamics of outlet glaciers, may be the primary control on Greenland's future state of balance.

Perhaps more importantly, the simulations confirm that the longest standing bogeyman in glaciology, the so-called "marine ice sheet instability"12,13, is alive and well. According to this hypothesis, if a glacier rests on a bed below sea level that slopes downwards inland, its retreat into deeper water will be re-inforced by acceleration and thinning until the bedrock slope reverses (and the glacier encounters shallower water) or until some other "braking" mechanism halts its retreat. In the case of Helheim glacier, retreat was halted in 2006 by a combination of shallower water and the re-establishment of a floating ice tongue, which provides some resistance to flow ${ }^{5,7}$. Had that not occurred, Nick and colleagues show that shoaling bedrock topography would have stopped the retreat several 10's of kilometres farther inland.

In Greenland, there are few places where the bedrock topography remains below sea level far inland from the coast. Therefore, according to the work by Nick and colleagues ${ }^{5}$, for most of Greenland's outlet glaciers, dynamic mass losses are expected to be short-lived. One exception is beneath Jacobshavn Isbræ, Greenland's largest outlet glacier, where a 


\section{References}

1. Zwally, H. J. et al. Surface melt-induced acceleration of Greenland ice-sheet flow. Science, 297, 218-222 (2002).

2. Thomas, R. H. et al. Investigation of surface melting and dynamics thinning on Jakobshavn Isbræ, Greenland. J. Glaciol., 49, 231-239 (2003).

3. Thomas, R. H. Force-perturbation analysis of recent thinning and acceleration of Jakobshavn Isbræ, Greenland. J. Glaciol., 50, 57-66 (2004).

4. Joughin, I., W. Abdalati, and M. Fahnestock. Large fluctuations in speed on Greenlands Jakobshavn Isbræ glacier. Nature, 432, 608-610 (2004).

5. Nick, F. M., A. Vieli, I. M. Howat, and I. Joughin. Large-scale changes in Greenland outlet glacier dynamics are triggered at the terminus. Nature Geosci., xxx-yyy (2009).

6. IPCC. Climate Change, 2007: the physical basis. Contribution of Working Group I to the Fourth Assessment Report of the Intergovernmental Panel on Climate Change. Technical report, S. Solomon et al., Cambridge Univ. Press (2007).

7. Howat, I. M., I. Jougin, and T. A. Scambos. Rapid changes in ice discharge from Greenland's outlet glaciers. Science, 315, 1559-1561 (2007).

8. Joughin, I. et al. Seasonal speedup along the western flank of the Greenland ice sheet. Science, 320, 781-783 (2008).

9. Holland, D. M., R. H. Thomas, B. D. Young, M. H. Ribergaard, and B. Lyberth. Acceleration of Jakobshavn Isbræ triggered by warm subsurface ocean waters. Nature Geosc. 1 659-664 (2008). 
deep bedrock trough extends far into the ice sheet interior. Interestingly, and perhaps not coincidentally, Jacobshavn continues to accelerate, thin, and retreat to this day ${ }^{14}$.

In Antarctica, the story is quite different. Here, many hundreds of thousands of square kilometres of the ice sheet rest on bedrock below sea level. The observations in Greenland and the model simulations by Nick and colleagues suggest that the potential for large-scale ice sheet instability in Antarctica is indeed real.

\section{Figure (photo credit Gordon Hamilton):}

The calving front of Helheim Glacier, East Greenland, as seen from the air in 20XX. Numerical modeling of Nick et al. successfully mimic the pattern of acceleration, thinning, retreat, and stabilization observed on this large outlet glacier from $\sim 2002-2006$, providing strong support for the contention that perturbations at the marine calving front were responsible for it's behaviour over that period of time. 
10. Sole, A., A. Payne, J. Bamber, P. Nienow, and W. Krabill. Testing hypothesis of the cause of peripheral thinning of the Greenland Ice Sheet: is land-terminating ice thinning at anomalously high rates? The Cryosphere, 2, 205-218 (2008).

11. Rignot, E. and P. Kanagaratnum. Changes in the velocity structure of the Greenland Ice Sheet. Science, 311, 986-990 (2006).

12. Weertman, J. Stability of the junction of an ice sheet and an ice shelf. J. Glaciol., $13,3-13(1974)$.

13. Schoof, C. Ice sheet grounding line dynamics: Steady states, stability, and hysteresis. J. Geophys. Res., 112, F03\$28 (2007).

14. Joughin, I. et al. Continued evolution of Jakobshavn Isbræ following its rapid speedup. J. Geophys. Res., 113, F04006 (2008). 